\title{
Economics of Production of Ginger in Wayanad District of Kerala, India
}

\author{
Merlin Mathew ${ }^{1^{*}}$, N. Vani ${ }^{2}$ and B. Aparna ${ }^{2}$ \\ ${ }^{1}$ Agricultural Economics, Sri Venkateswara Agricultural College, Tirupati, Andhra Pradesh, India \\ ${ }^{2}$ Department of Agricultural Economics, Sri Venkateswara Agricultural College, Tirupati, Andhra Pradesh, India \\ "Corresponding author: merlin0703@gmail.com
}

\begin{abstract}
The present study was aimed to find out the input use levels and economics of ginger cultivation in Wayanad district of Kerala, during the crop year 2015-16. Total four villages which are leading in the area of ginger cultivation were selected and twenty farmers from each village i.e. total 80 farmers were chosen randomly as sample size. The study indicated that cost of cultivation and gross returns were positively related with size of the holding. The overall cost of cultivation was ₹ 4, 54,991.62 and ₹ 4, 94,501.03 per hectare on small and large farms. The expenditure on seed was found to be maximum constituting about 35.01 per cent of total cost followed by human labour, and machine power. All the farm income measures exhibited a positive relationship with the farm size. Returns per rupee of expenditure were found to be ₹ 0.60 and 0.67 per hectare on small and large farms respectively.
\end{abstract}

Keywords: break even output, cost concepts, farm income measures, margin of safety

Ginger is one of the earliest known oriental spices and is being cultivated in India for both as a fresh vegetable and as a dried spice since time immemorial. It is the most popular hot, fragrant, kitchen spice in the world. Ginger has a long documented history of both culinary and medicinal use throughout the history. In Indian Ayurvedic medicine, ginger is used as an anti-inflammatory and in Indian cuisine; ginger is the most important ingredient. About 50 percent of the global demand for ginger is met by India. India is the largest producer, consumer and exporter of ginger in the world with an area of 140 thousand hectares (2013) and a production and productivity of 688.30 thousand tonnes and 4,916 $\mathrm{kg} /$ hectares (2013) respectively. India is the leading exporter of ginger in the world. In the year 2014-15 India fetched a value of Rs. 33,133 lakhs in export of ginger. Ginger is grown in almost all parts of India since time immemorial. In India, Mizoram and Assam, Jharkand, West Bengal and Kerala are the leading producers of ginger. These states contribute more than 50 per cent of the total ginger production. Kerala stands fourth in area $(4,538$ hectares) with a production of 21,521 tonnes (2013). The first grade export quality cured ginger (Cochin ginger or Calicut ginger) is produced in Kerala state. It fetches a premium price because of its superior quality. In Kerala, the ginger crop is cultivated in all the 14 districts and is one of the most important cash crops grown in wayanad district. Due to the peculiar nature of soil and climate, the area under ginger cultivation has been mostly concentrated in this district. Wayanad stood first in area, 1,992 hectares (2013) with a production of 11,006 tonnes, followed by Palakkad with an area and production of 836 hectares and 4,080 tonnes (2013) respectively. Wayanad district contributes to more than 50 per cent of the total state production.

Though Wayanad district is an important area for the production of ginger in Kerala, India, little information is available on the economic viability of the crop in this region. In this context, it is felt necessary to conduct a micro level study and examine the economic aspects of production of ginger. 


\section{Objectives}

1. To study the input use levels in ginger cultivation

2. To study the cost and returns in the ginger cultivation.

\section{MATERIALS AND METHODS}

Wayanad district having the first place in the production of ginger in the state was purposively selected for the study. Then, two blocks - Panamaram and Sulthan Bathery- of Wayanad district were selected and from these blocks, a list of villages under ginger crop was arranged in the descending order of their acreage. The first two villages from each block with highest area under the selected crop were choosen for a detailed study. The farmers were stratified into small and large groups on the basis of operational holding as per the criterion adopted by IRDP. Those farmers with 2 hectares or less of dry land were considered as small farmers and the farmers with more than 2 hectares of dry land were considered as large. From each of the selected villages, 10 farmers in each size group from each village were selected at random. Thus 40 small and 40 large farmers constituted the sample of the study. The total number of ginger growers selected for the purpose of study was 80 .

The data used in the study to fulfill various objectives were collected from the selected farmers through personal interview with the help of pretested schedules designed for the purpose. Simple tabular analysis was carried out to work out the levels of input utilization and cost of production of ginger.

Cost concepts defined by Commission for Agricultural Costs and prices (CACP) were followed. Cost concepts were used to estimate the cost of cultivation and to derive the measures of efficiency viz., farm business income, family labour income, net income and farm investment income. The cost concepts viz., Cost $\mathrm{A}_{1^{\prime}}$ Cost $\mathrm{A}_{2^{\prime}}$ Cost $\mathrm{B}_{1^{\prime}}$ Cost $B_{2}$, Cost $C_{1}$ Cost $C_{2}$ and Cost $C_{3}$ were used in the present study and they are derived as follows.

\section{Cost $\mathbf{A}_{1}$}

This cost includes value of hired human labour, owned and hired cattle labour, owned and hired tractor services, seeds, fertilizers, farm yard manure, plant protection chemicals, depreciation, repairs, land revenue and interest on working capital.

\section{Cost $\mathrm{A}_{2}$}

Cost $A_{1}+$ rent paid for leased in land. In the present study, all the selected farmers were owner cultivators. Hence, Cost $A_{1}$ and $A_{2}$ were one and the same.

\section{Cost $B_{1}$}

Cost $A_{1}+$ interest on value of owned capital assets (excluding land)

\section{Cost $\mathrm{B}_{2}$}

Cost $B_{1}+$ rental value of owned land (net of land revenue) and rent paid for leased-in land.

Cost $\mathrm{C}_{1}$

Cost $B_{1}+$ imputed value of family labour

Cost $\mathrm{C}_{2}$

Cost $B_{2}+$ imputed value of family labour

\section{Cost $\mathrm{C}_{3}$}

Cost $C_{2}+10$ per cent of Cost $C_{2}$ as management cost (on account of managerial functions performed by farmers.

\section{Farm efficiency measures}

$\begin{aligned} \text { Farm business income = } & \text { Gross income }- \text { Cost } A_{1} \\ & \left(\text { Cost } A_{2} \text { in case of tenant }\right. \\ & \text { operated land }) \\ = & \text { Gross income }- \text { Cost } B_{2} \\ \text { Family labour income }= & \text { Gross income }- \text { Cost } C_{2} \\ \text { Net Income } & \left(\text { Gross income }- \text { Cost } C_{3}\right)+ \\ \text { Farm investment income }= & \left(\text { Cost } B_{2}-\text { Cost } A_{2}\right)\end{aligned}$

\section{Break-Even analysis}

A break-even analysis is the determination of the functional relationship of revenue and costs to output rate and the derivation of functional relation of profit to output as residual. A break-even chart is a diagram of the short run relation of total cost and total revenue to rate of output. When actual costs are segregated into fixed and variable costs, any variation in volume will cause a change in variable costs and in turn, on the contribution and 
profit. The management has, therefore to know the effect of such an increase in output on its profits and a study of cost-volume-profit relations enables management to plan profits.

A break-even analysis chart can be defined as a chart which shows neither profit nor loss at various levels of activity, the level at which neither profit nor loss is shown being called the break-even point. A firm is said to be at break-even point when its costs are equal to revenue i.e., when the contribution margin is exactly equal to the fixed costs. The break-even analysis is the methodology used to calculate that level of output at which the firm neither makes profit nor suffers loss. The appropriate formula to estimate the break-even output is.

Break even output $=$

Total fixed costs

Selling price per unit of output -

Variable costs Per unit

\section{RESULTS AND DISCUSSION}

\section{Average size of land holding}

The scale and efficiency of production and income earning capacity of farm business depends on the size of the holding. Table 1 presents land holding particulars of the sample farmers.

Table 1: Average size of land holding of sample farmers (hectares)

\begin{tabular}{cccc}
\hline $\begin{array}{c}\text { Sl. } \\
\text { No. }\end{array}$ & Particulars & Small & Large \\
\hline 1 & Dry land & $1.27(94.07)$ & $2.69(91.50)$ \\
2 & Irrigated land & $0.08(5.93)$ & $0.25(8.50)$ \\
3 & Total & $1.35(100)$ & $2.94(100)$ \\
4 & Area under ginger & $0.32(23.70)$ & $0.70(23.81)$ \\
\hline
\end{tabular}

The average size of the land holding varied from 1.35 hectares on the small farms to 2.94 hectares on the large farms. Of the 1.35 hectares operated by small farmers, the share of the irrigated land was 0.08 hectares and that of dry land was 1.27 hectares. On large farms, the irrigated land constituted 0.25 hectares and the dry land 2.69 hectares. This clearly indicated the predominance of dry land cultivation. In the study area, most of the crops are raised under rainfed condition.
The area under ginger, a selected enterprise for an economic analysis ranged from 0.32 hectares on small farms to 0.70 hectares on large farms. The proportionate area allocated for ginger cultivation appeared to be almost equal on both the farms.

\section{Input utilization}

Human labour utilization was positively related with the size of holding. Male and female labour utilization were highest in large size group of holdings (Table 1). The overall average labour utilization was 332.72 mandays per hectare in small farms and 387.64 mandays per hectare in large farms. Human labour was utilized for all the operations except ploughing, for which machinery services were employed (47.32 hours/ha). Machinery use showed a negative relationship with the farm size.

The quantity of rhizomes increased with increase in size of the holding. It was highest in the large size groups $(2633.5 \mathrm{~kg} / \mathrm{ha})$ followed by small farms $(2393.5 \mathrm{~kg} / \mathrm{ha})$. The average quantities of manures applied by the selected farmers were 18.96, 18.6 and 18.72 tonnes/ha on small and large farms respectively. The levels of application of $\mathrm{N}$, $\mathrm{P}, \mathrm{K}$ increased with the size of the holding. The expenditure on plant protection chemicals was highest on large farms.

Table 2: Input utilization in ginger cultivation per hectare

\begin{tabular}{cccc}
\hline S1. No. & Particulars & Small & Large \\
\hline 1 & Human labour (mandays/ha) & & \\
V3\\
33 & Owned & 24.87 & 4.62 \\
& Hired & 307.85 & 383.02 \\
2 & Machine power (hours/ha) & & \\
& Owned & - & - \\
& Hired & 52.41 & 44.91 \\
3 & Seeds (kgs) & 2393.5 & 2633.5 \\
4 & Manures (tonnes) & 18.96 & 18.6 \\
5 & Fertilizers (kgs) & & \\
& N & 177.5 & 206.88 \\
& P & 155 & 179.33 \\
& K & 160 & 135.1 \\
& S & 37.5 & 33.73 \\
& Plant protection chemicals (L) & 5.99 & 7.79 \\
\hline
\end{tabular}




\section{Cost of cultivation}

Seed rhizomes, human labour, machine use, manures, rental value of land were the major items of cost on all the size groups and it accounted for more than 80 per cent of the total cost (Table 3). The cost of cultivation ( $\operatorname{cost} c_{2}$ ) was found to be Rs. 4, 54,991.62 and ₹ 4, 94,501.03 on small and large farms respectively. Cost of cultivation according to the cost concepts revealed the same. Costs, $A_{1^{\prime}} A_{2^{\prime}}$ $\mathrm{B}_{1}, \mathrm{~B}_{2}, \mathrm{C}_{1}, \mathrm{C}_{2}, \mathrm{C} 3$ showed positive relationship with the farm size (Table 3).

Table 3: Cost of cultivation of ginger according to farm size and component wise (In rupees per hectare)

\begin{tabular}{|c|c|c|c|}
\hline $\begin{array}{l}\text { Sl. } \\
\text { No. }\end{array}$ & Particulars & Small & Large \\
\hline \multicolumn{4}{|l|}{1.} \\
\hline \multirow[t]{5}{*}{ (a) } & Human labour & $\begin{array}{c}1,46,396.80 \\
(32.18)\end{array}$ & $\begin{array}{c}1,70,561.60 \\
(34.49)\end{array}$ \\
\hline & Owned & $10,942.80$ & $2,032.80$ \\
\hline & & $(2.41)$ & $(0.41)$ \\
\hline & Hired & $1,35,454.00$ & $1,68,528.80$ \\
\hline & & (29.77) & $(34.08)$ \\
\hline \multirow[t]{4}{*}{ (b) } & Machine use & & \\
\hline & Owned & - & - \\
\hline & Hired & $41,928.00$ & $35,928.00$ \\
\hline & & $(9.22)$ & $(7.27)$ \\
\hline \multirow[t]{2}{*}{ (c) } & Seeds & $1,57,827.00$ & $1,73,652.00$ \\
\hline & & $(34.69)$ & $(35.12)$ \\
\hline \multirow[t]{2}{*}{ (d) } & Manures & $36,061.6$ & $35,679.46$ \\
\hline & & $(7.92)$ & $(7.21)$ \\
\hline \multirow[t]{2}{*}{ (e) } & Fertilizers & $8,915.00$ & $9,238.60$ \\
\hline & & $(1.96)$ & $(1.87)$ \\
\hline \multirow[t]{2}{*}{ (f) } & Plant protection chemicals & $2,450.94$ & $3,381.35$ \\
\hline & & $(0.54)$ & $(0.68)$ \\
\hline \multirow[t]{2}{*}{ (g) } & Repairs and maintenance & 472.00 & $1,370.00$ \\
\hline & charges & $(0.10)$ & $(0.28)$ \\
\hline \multirow{4}{*}{ (h) } & Interest on working capital & $19,948.85$ & $21,759.18$ \\
\hline & & $(4.38)$ & $(4.40)$ \\
\hline & Total operational costs & $4,14,000.19$ & $4,51,570.19$ \\
\hline & & $(90.99)$ & $(91.32)$ \\
\hline \multicolumn{4}{|l|}{2.} \\
\hline \multirow[t]{2}{*}{ (a) } & Land revenue & 550 & 550 \\
\hline & & $(0.12)$ & $(0.11)$ \\
\hline \multirow[t]{2}{*}{ (b) } & Rental value of owned & 36,250 & 37,500 \\
\hline & land & $(7.97)$ & (7.58) \\
\hline \multirow[t]{2}{*}{ (c) } & Depreciation & $2,062.89$ & $2,333.86$ \\
\hline & & $(0.45)$ & $(0.47)$ \\
\hline
\end{tabular}

(d) Interest on fixed capital

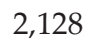

$2,546.98$

(0.47)

Total fixed costs

$40,991.43$

$42,930.84$

(9.01)

(8.68)

Total costs

$4,54,991.62 \quad 4,94,501.03$

(100)

(100)

Note: Figures in the parenthesis indicate percentage to the total.

\section{Output and returns from ginger cultivation}

The small and large farms realized a gross income of $₹ 7,27,281.82$, ₹ 8, 27,336 and per hectare respectively. The net income also exhibited a positive relationship with the farm size (Table 4).

Table 4: Costs concepts - ginger (Rupees per hectare)

\begin{tabular}{cccc}
\hline $\begin{array}{c}\text { Sl. } \\
\text { No. }\end{array}$ & Particulars & Small & Large \\
\hline \multirow{2}{*}{1} & Cost $\mathrm{A}_{1} / \mathrm{A}_{2}$ & $4,05,670.28$ & $4,52,421.25$ \\
& & $(89.16)$ & $(91.49)$ \\
2 & Cost $\mathrm{B}_{1}$ & $4,07,798.82$ & $4,54,968.23$ \\
& & $(89.63)$ & $(92.01)$ \\
3 & Cost $\mathrm{B}_{2}$ & $4,44,048.82$ & $4,92,468.23$ \\
& & $(97.59)$ & $(99.59)$ \\
4 & Cost $\mathrm{C}_{1}$ & $4,18,741.62$ & $4,57,001.03$ \\
& & $(92.03)$ & $(92.42)$ \\
5 & ${\text { Cost } \mathrm{C}_{2}}$ & $4,54,991.62$ & $4,94,501.03$ \\
& & $(100)$ & $(100)$ \\
6 & ${\text { Cost } \mathrm{C}_{3}}^{*}$ & $5,00,490.78$ & $5,43,951.13$ \\
& & $(110)$ & $(110)$ \\
\hline
\end{tabular}

Note: Figures in the parentheses indicate percentage to the $\operatorname{Cost} C_{2}$.

Table 5: Output and returns from ginger cultivation

\begin{tabular}{ccccc}
\hline $\begin{array}{c}\text { S1. } \\
\text { No. }\end{array}$ & Particulars & Units & Small & Large \\
\hline $\mathbf{1}$ & Yield in physical units & & \\
\hline \multirow{2}{*}{ (a) } & \multirow{2}{*}{ Ginger } & Quintals & 253.13 & 285.46 \\
& & & $(94.18)$ & $(94.86)$ \\
(b) & \multirow{2}{*}{ Seed purpose } & Quintals & 15.64 & 15.48 \\
& & & $(5.82)$ & $(5.14)$ \\
& \multirow{2}{*}{ Total output } & Quintals & 268.77 & 300.94 \\
& & $(100)$ & $(100)$ \\
\hline
\end{tabular}

2. Yield in monetary terms

\begin{tabular}{ccccc}
\hline (a) & Ginger & $₹$ & $6,41,261.82$ & $7,42,196.00$ \\
(b) & Seed purpose & $₹$ & $86,031.00$ & $85,140.00$ \\
& Gross returns & $₹$ & $7,27,281.82$ & $8,27,336.00$ \\
& Cost of cultivation & $₹$ & $4,54,991.62$ & $4,94,501.03$ \\
& Net returns & $₹$ & $2,72,289.2$ & $3,32,834.97$ \\
\hline
\end{tabular}

Note: Figures in the parentheses indicate percentage to the total output. 


\section{Cost of production}

The particulars on costs and returns per quintal of ginger are presented in Table 6 . The contents of the Table 5 revealed that the cost of production was inversely related with the farm size. Cost per quintal of ginger decreased from ₹ 1,692.86 on small farms to ₹ $1,643.19$ on large farms. A quintal of ginger resulted in a net income of ₹ 1,013.10 on small farms, $₹ 1,105.98$ on large farms.

Table 6: Costs and returns per quintal of ginger production (Rupees per quintal)

\begin{tabular}{cccc}
\hline S1. No. & Particulars & Small & Large \\
\hline $\mathbf{1}$ & Costs & & \\
\hline (a) & Variable costs & $1,540.35$ & $1,500.53$ \\
(b) & Fixed costs & 152.51 & 142.66 \\
(c) & Total costs & $1,692.86$ & $1,643.19$ \\
\hline $\mathbf{2}$ & Returns & & \\
\hline (a) & Gross returns & $2,705.96$ & $2,749.17$ \\
(b) & Net returns & $1,013.10$ & $1,105.98$ \\
\hline
\end{tabular}

\section{Measures of farm income}

Measures of farm income are represented in Table 7. Gross income exhibited direct relationship with the farm size and it was in the order of ₹ 7, 27,281.28 and ₹ 8, 27,336 per hectare on small and large farms respectively. The gross income was more by ₹ 1 , $00,054.72$ on large farms due to higher productivity attained by this category of farms. Net income which represents the surplus of income over total cost was estimated at ₹ 2, 72,289.66 on small farms as against $₹ 3,32,834.97$ on large farms. The trend of net income revealed that large farmers were more efficient than the small farmers in the utilization of resources in the cultivation of ginger. Farm business income is a measure which indicates return to owned resources like land, capital and labour. On this front also, large farmers were distinctly superior to small farmers in tapping maximum productivity out of these resources. It was ₹ 3, 21,611 on small farms and ₹ 3, 74,914.75 on large farms. Family labour income is another measure of farm efficiency representing the returns from farmers own labour and family labour. Large farmers derived more family labour income amounting to ₹ 3, 34,867.77 as against $₹ 2$, 83,232.46 on small farms. Farm investment income is a measure that indicates returns to fixed capital. It was ₹ 3, 10,668.20 and ₹ 3, 72,881.95 per hectare on small and large farms respectively. Large farmers were able to realize a net income of ₹ 0.67 per rupee of expenditure, while the small farmers realized ₹ 0.60 .

Table 7: Measures of farm income - ginger production(Rupees per hectare)

\begin{tabular}{cccc}
\hline $\begin{array}{r}\text { S1. } \\
\text { No. }\end{array}$ & Particulars & Small & Large \\
\hline \multirow{2}{*}{1} & Gross income & $7,27,281.28$ & $8,27,336$ \\
& & $(100)$ & $(100)$ \\
2 & Net income & $2,72,289.66$ & $3,32,834.97$ \\
& & $(37.44)$ & $(40.23)$ \\
3 & Farm business income & $3,21,611$ & $3,74,914.75$ \\
& & $(44.22)$ & $(45.32)$ \\
4 & Family labour income & $2,83,232.46$ & $3,34,867.77$ \\
& & $(38.94)$ & $(40.48)$ \\
5 & Farm investment income & $3,10,668.2$ & $3,72,881.95$ \\
& & $(42.72)$ & $(45.07)$ \\
6 & Returns per rupee of & 0.60 & 0.67 \\
\hline
\end{tabular}

Note: Figures in the parentheses indicate percentage to the gross income.

\section{Break-even analysis}

Break-even analysis of ginger cultivation according to size groups are presented in Table 8 .

Table 8: Break-even analysis - ginger cultivation

\begin{tabular}{cccc}
\hline $\begin{array}{c}\text { S1. } \\
\text { No. }\end{array}$ & Particulars & Small & Large \\
\hline 1 & Total Fixed Costs (₹) & $40,991.43$ & $42,930.84$ \\
2 & $\begin{array}{c}\text { Variable cost } \\
(₹ / \text { Quintal) }\end{array}$ & $1,540.35$ & $1,500.23$ \\
3 & $\begin{array}{c}\text { Price (₹/Quintal) } \\
\text { Break-even output } \\
\text { (Quintals) } \\
4\end{array}$ & $2,533.33$ & 2,600 \\
5 & $\begin{array}{c}\text { Average output } \\
\text { (Quintals) } \\
\text { Margin of safety } \\
\text { (Quintals) }\end{array}$ & 268.77 & 39.04 \\
7 & $\begin{array}{c}\text { Percentage BEO to } \\
\text { average output }\end{array}$ & 15.36 & 14.91 \\
\hline
\end{tabular}

The break even out-put on small and large farms was 41.28 and 39.04 quintals per hectare respectively. It is apparent that the average yields obtained by small and large farms exceeded the minimum output to be produced. The margin of safety stood at 227.49 
and 261.90 quintals on the above said categories of farms. This margin of safety confirmed the ability of farmers to cope up with the eventualities in ginger cultivation.

\section{CONCLUSION}

The cost of cultivation of ginger was directly related with the size of the holding. It was ₹ $4,54,991.62$ on small farms and ₹ 4, 94,501.03 on large farms. The cost of human labour, seeds, manures and rental value of owned land accounted for more than 80 per cent of the total cost. The cost of producing a quintal of ginger exhibited inverse relationship with the size of the holding as it was ₹ 1643.19 on large farms and $₹ 1692.86$ on small farms. A quintal of ginger yielded a net income of ₹ 1013.10 and $₹ 1105.98$ on small and large farms respectively. The returns per rupee of expenditure were ₹ 0.60 and $₹ 0.67$ on small and large farms.

\section{REFERENCES}

Bharathi, S. Bhat, Murthy, C., Mohammed Yusuf. 2012. Economics of production of ginger in Uttar Kannada district of Karnataka. International Research Journal of Agricultural Economics and Statistics, 3(1).

Dodke, L.B., Kalamkar, S.S., Shende, N.V. and Deoghare, B.L. 2002. Economics of production and marketing of turmeric. Indian Journal of Agricultural Marketing, 16(2): 70-75.

Gaikwad, S. H., Thorve, P. V. and Bhole, B. D. 1998. Economics of ginger (Zingiber officinale Rosc.) production in Amravati district (Maharashta, India). Journal of Aromatic Crops and Spices, 7(1): 7-11.

Jagatap, P.P., Shingane, U.S. and Kulkarni, K.P. 2012. Economics of chilli production in India. African Journal of Basic and Applied Sciences, 4(5): 161-164.

Janailin, S., Papang and Tripathi, A.K. 2014. Costs and returns structure of turmeric (Curcuma longalinn) and constraints faced by producers in Jaintia hills district of Meghalaya India. Indian Journal of Agricultural Research, 48(3): 192-198.

Karthik, V. and Amarnath, J.S. 2014. An economic analysis of turmeric production in Tamil Nadu, India. Direct Research Journal of Agriculture and Food Science, 2(6): 66-76. 